\title{
Impediments to the Use of E-Learning to Teach Gymnastics Course in Faculties of Physical Education
}

\author{
Eman Kamal Eldin Ebrahim Elmasarawy ${ }^{1}$ \\ ${ }^{1}$ Lecturer in the Department of the theories and applications of gymnastics, exercises and Sports Shows, Faculty of Physical \\ Education, Sadat City University, Egypt
}

\begin{abstract}
Research Objectives: This research aims at designing a Questionnaire to identify the Impediments of using E-learning to teach Gymnastics courses in Faculties of Physical Education, along with identify the following: 1-Impediments related to technical and administrative aspects and the order of its effect. 2-Impediments related to Faculty Members and the order of its effect. 3-Impediments related to students and the order of its effect. 4-Impediments related to Gymnastics course and the order of its effect. Research Methodology: descriptive approach was used. Research Sample: Research Sample consisted of (50) Faculty Members who teaches Gymnastics course in (12) faculties. This sample was randomly selected after distributing the website for Questionnaire on Gymnastics department in Faculties of Physical Education in the Egyptian Universities. Conclusions: There are Impediments obstructing Faculty Members from using e-learning to teach Gymnastics courses in Faculties of Physical Education. Impediments related to technical and administrative aspects were in the first order between study axes with an arithmetic average of (4.066). The most significant Impediments within the axis were the slow Internet connection and interruption of communication taking a lot of time in lecture. 2-Impediments related to students were in the second order among the axes of the study with an arithmetic average of (4.02). The most important Impediments within the axis is the preoccupation of students in sites of no relation to e-learning. 3-Impediments related to Gymnastics course were in the third order among the axes of the study with an arithmetic average of (3.609). The most important Impediments within the axis is the difficulty in carrying out evaluation activities for Gymnastics course when using e-learning. 4-Impediments related to Faculty Members were in the fourth order among the axes of the study with an arithmetic average of (3.606). The most important Impediments within the axis is the lack of internet points in the offices of Faculty Members.
\end{abstract}

\section{Introduction and Research Problem}

$\mathrm{E}$ ducation is a cornerstone of development and progress for societies. As well-educated and qualified individuals are deemed to be the real wealth of any society. Accordingly, investing in the human element is one of the trends for which the world's universities compete.

This has led the educational institutions and its cadres to adopt new forms of education, the most prominent of which is e-learning. Its applications have diversified to become more widespread and used in numerous specialities. (1:261)

E-learning plays an important role in the development of teaching and learning processes. This is demonstrated by the ability of a learner to choose the information and experience he needs in time and at the speed suitable to him; so he does not engage himself in class schedules. Moreover, a learner can repeat and reiterate learning as much as he needs without feeling embarrassed. E-learning provides a great amount of information without the need for attendance at libraries. Furthermore, E-learning provides time and effort of a teacher for guidance, direction and preparation of student activities. E-learning also provides various forms of interaction between teacher and learner, focusing on feedback to guide a learner to the right path, in addition to the quick updating of educational material and providing learners with the same, along with reducing costs of publishing. (5 :51-53)

Good preparation of E-courses achieves the goals of education. It also affects the learner's interaction and satisfaction with education. E-courses are provided to students either on CD-ROM or computer or through the Internet. However, online courses are characterized by being provided fast and for a large number of users, along with allowing development and updating to its content. $(9: 231)$ 
Findings of many studies indicate the effectiveness of using learning environments designed by using E-learning in the development of cognitive acquisition, along with the formation of positive attitudes for individuals, where the state-of-the- art technology devices are harnessed, from electronic presentation techniques to multimedia, search engines, electronic libraries and internet portals from which a learner benefits in the university education system. (18)، (19)، (23)

Gymnastics course is one of the courses taught in faculties of Physical Education in Egyptian Universities, so it is necessary to benefit from the technological revolution in learning motor skills, as well as the development of methods and techniques of its teaching.

Despite the importance of E-learning, as well as the many findings that have proven its success, its use to teach Gymnastics courses in Faculties of Physical Education is still very limited. E-learning faces some Impediments and challenges, along with that there are faculties that have not activated any electronic courses to teach Gymnastics courses yet.

Given E-learning is a necessity dictated by changes of contemporary time, and in order to identify and determine the problem of study scientifically and correctly, the Researcher conducted this study to try identifying the Impediments to the use of E-learning facing Faculty Members when applying E-learning systems to teach Gymnastics course.

\section{Research Objectives}

This research aims at designing a Questionnaire to identify the Impediments of using E-learning to teach Gymnastics courses in Faculties of Physical Education, along with identify the following:

1-Impediments related to technical and administrative aspects and the order of its effect.

2-Impediments related to Faculty Members and the order of its effect.

3-Impediments related to students and the order of its effect.
4-Impediments related to Gymnastics course and the order of its effect.

\section{Research Questions}

1-What are the Impediments to the use of E-learning to teach Gymnastics course related to technical and administrative aspects and the order of its effect?

2-What are the Impediments to the use of E-learning to teach Gymnastics course related to Faculty Members and the order of its effect? 3-What are the Impediments to the use of E-learning to teach Gymnastics course related to students and the order of its effect?

4-What are the Impediments to the use of E-learning to teach Gymnastics course related to Gymnastics course and the order of its effect?

\section{Research Terms}

\section{E-Course:}

A course based on the integration between educational material and E-learning technology in its design, preparation, application and evaluation. A student studies its contents technologically and interactively with Faculty Members whenever and wherever he desires to do so. $(3: 86)$

\section{Impediments to the use of E-learning}

Problems and difficulties that preclude Faculty Members from using E-learning to teach Gymnastics course in Faculties of Physical Education. (Operational Definition)

\section{Research Methodology}

Descriptive Approach was used

\section{Research Sample}

Research Sample consisted of (50) Faculty Members who teaches Gymnastics course in (12) faculties. This sample was randomly selected after distributing the website for Questionnaire on Gymnastics department in Faculties of Physical Education in the Egyptian Universities. Individual of study sample were distributed as follow: 
Table (1)

\begin{tabular}{|c|c|c|c|}
\hline Data & Classification & Number & Percentage \\
\hline \multirow{3}{*}{ Academic Degree } & Teaching Assistant & 14 & $28 \%$ \\
\cline { 2 - 4 } & Associate Professor & 12 & $24 \%$ \\
\cline { 2 - 4 } & PH.D Professor & 14 & $28 \%$ \\
\cline { 2 - 4 } & Professor Emeritus & 50 & $20 \%$ \\
\hline
\end{tabular}

In addition, (20) Faculty Members were selected from the same research population, and outside the basic sample in order to conduct the scientific transactions (truthfulnessstability) of the Questionnaire in question.

\section{Research Tool}

Questionnaire was used as a data collection tool. ( the Impediments of the use of E - learning to teach Gymnastics course Questionnaire)

\section{Application of Study}

The website of the Questionnaire was distributed to the study sample of Faculty Members of Gymnastics from 3th September 2018 to 28 January 2019.

\section{Statistical Methods Used}

Based on the nature of the study and the objectives it seeks to achieve, Statistical Package for the Social Sciences (Spss) program was used, based on the following statistical methods:
1-Pearson Correlation Coefficient

2-Cronbach's Alpha Reliability Coefficient.

3-Frequency and Percentage

4-Arithmetical Averages

\section{5-Standard Deviations}

Criteria of Evaluating the Importance of Impediments to E-learning

The following criteria were used to determine the effectiveness of Impediments of E-learning from the point of view of Faculty Members; in order to facilitate the interpretation of the results. The Researcher used the following method, depending on weighting the criteria by the following calculation equation:

Category Length $=($ the largest value - the lowest value $) \div$ Number of Categories $=(5-1) \div 5=0.8$

Table (2)

\begin{tabular}{|c|c|}
\hline Arithmetic Average of Response to Statement & Degree of Impediments Effect \\
\hline Less than 1.8 & Very Low \\
\hline From 1.8 To less than 2.6 & Low \\
\hline From 2.6 To less than 3.4 & Moderate \\
\hline From 3.4 To less than 4.2 & High \\
\hline From 4.2 and More & Very High \\
\hline
\end{tabular}

\section{Research Results}

\section{First, Presentation and Discussion of First Question's} Results

The First Question states that:
1-What are the Impediments to the use of E-learning to teach Gymnastics course related to Technical and Administrative Aspects and the order of its effect?

For answering such question, the frequency and arithmetic average of the responses of research sample on technical and administrative aspects were calculated in order to determine the degree of Impediments effect and its Order from their point of view, and the results were as follows: 
Table (3)

Ordering and Degree of Effect of Impediments Related to Technical and Administrative Aspect

\begin{tabular}{|c|c|c|c|c|c|}
\hline $\begin{array}{l}\text { Ordering By } \\
\text { Effect }\end{array}$ & $\begin{array}{c}\text { Number of Statement } \\
\text { on Questionnaire }\end{array}$ & Impediments & $\begin{array}{l}\text { Arithmetic } \\
\text { Average }\end{array}$ & $\begin{array}{l}\text { Standard } \\
\text { Deviation }\end{array}$ & $\begin{array}{l}\text { Degree of } \\
\text { Effect }\end{array}$ \\
\hline 1 & 8 & $\begin{array}{l}\text { Slow Internet connection and interruption of } \\
\text { communication take long time in E-learning in the lecture }\end{array}$ & 4.6 & 0.67 & Very High \\
\hline 2 & 6 & $\begin{array}{l}\text { Incompatibility of numbers of computers with numbers of } \\
\text { students }\end{array}$ & 4.6 & 0.92 & Very High \\
\hline 3 & 1 & $\begin{array}{l}\text { Lounges are not equipped with the necessary equipment } \\
\text { for E-learning }\end{array}$ & 4.5 & 0.67 & Very High \\
\hline 4 & 4 & $\begin{array}{c}\text { Training programs offered for E-learning are not } \\
\text { commensurate with the actual needs of designing and } \\
\text { producing E-courses }\end{array}$ & 4.3 & 0.64 & Very High \\
\hline 5 & 3 & $\begin{array}{c}\text { Lack of financial resources to finance E-learning } \\
\text { requirements }\end{array}$ & 4.3 & 0.78 & Very High \\
\hline 6 & 5 & $\begin{array}{l}\text { Lack of specialized technicians to solve technical problems } \\
\text { when using E-learning }\end{array}$ & 4.2 & 0.75 & Very High \\
\hline 7 & 10 & $\begin{array}{c}\text { Lack of financial support to hold training courses for E- } \\
\text { learning }\end{array}$ & 4 & 0.78 & High \\
\hline 8 & 7 & $\begin{array}{l}\text { Incompatibility of technical support in solving some } \\
\text { technical problems, which leads to waste of lecture time }\end{array}$ & 4 & 1.1 & High \\
\hline 9 & 2 & Not organizing timings of schedule to allow E-learning & 3.8 & 0.75 & High \\
\hline 10 & 11 & $\begin{array}{l}\text { Lack of performing periodic maintenance for the internal } \\
\text { internet network in faculty }\end{array}$ & 3.8 & 1.2 & High \\
\hline 11 & 12 & Repeated power cuts & 3.6 & 0.8 & High \\
\hline 12 & 9 & $\begin{array}{l}\text { Lack of clarity of the regulations and mechanisms used to } \\
\text { activate E-learning for courses }\end{array}$ & 3.1 & 0.95 & Moderate \\
\hline
\end{tabular}

Table (3) shows that study sample agree on all the electronic labs, technical technicians, teachers and Impediments related to this axis. The Impediments with the order of 1 to 6 were of a "very high" effect. Study sample shows that the Slow Internet connection and interruption of communication take long time in Elearning in the lecture are deemed to be the most important Impediments related to this axis.

Impediments with order from 7 to 11 were of a "high" effect, as study sample considers that lack of financial support to hold training courses in E-learning is one of the Impediments affecting the use of E-learning to teach Gymnastics. Impediments with order of 12 was of a "moderate" effect, as study sample considers that the lack of clarity of regulations and mechanisms used to activate E-learning courses is one of the Impediments they face when using E-learning.

Abdullah Abdul Aziz (2005) points out that a requirement for activating E-learning in the educational process is to provide high-capacity internal and external Internet networks. (7:231)

Mohammed Al-Qadah (2002) states that a requirements of using E-learning includes the provision of infrastructure including laboratories, computers, corporate internal network, Internet network, CDs, electronic library, supervisors training programs and supervisors. (11: 12)

The findings of this study are consistent with the study of (Muhammad Fawzi) (2015) (12), and (Stevenson) (2007) (20) in the existence of Impediments to the use of Elearning in teaching, which are related to the technical and administrative aspects, including limited infrastructure and equipment necessary for E-learning, limited technical support in the lecture lounges, lack of training programs to enhance the competencies of Faculty Members to use Elearning.

\section{Second: Presentation and Discussion of First Question's Results}

The Second Question states that:

What are the Impediments to the use of E-learning to teach Gymnastics course related to Faculty Members and the order of its effect?

For answering such question, the frequency and arithmetic average of the responses of research sample on Questionnaire statements related to Faculty Members were calculated in order to determine the degree of Impediments effect and its Order from their point of view, and the results were as follows: 
Table (4)

Ordering and Degree of Effect of Impediments Related to Faculty Members

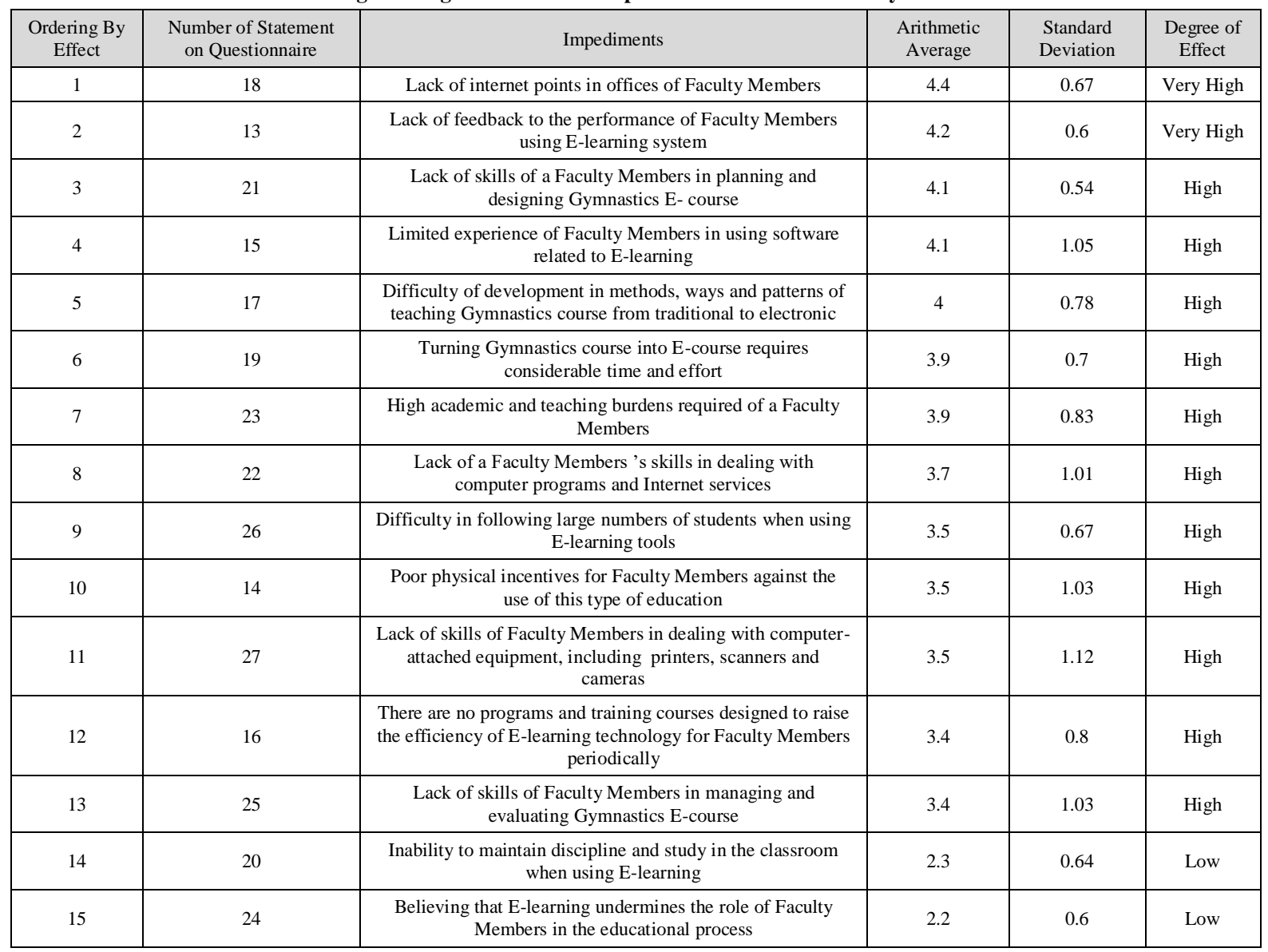

Table (4) shows that the study sample agrees on all Impediments related to this axis. Impediments with the order of 1 and 2 were of "very high" effect, and study sample considers that the lack of Internet points in the offices of Faculty Members is the most important Impediments related to this axis, hindering interaction and communication between a teacher and learner. Impediments with order of 3 to 13 were of "high" effect; as study sample considers that the lack of skills of planning and designing Gymnastics e-course for a Faculty Members is one of the Impediments affecting the use of elearning to teach Gymnastics course. Impediments with order of 14, 15 were of "low" effect, as a study sample considers that the Impediments of inability to maintain discipline and conduct of study inside the lounge when using e-learning, and the Impediments of believing that Elearning undermines the role of a Faculty Members in the educational process represent low Impediments when using E-learning.
According to Mohamed Ibrahim El-Desouki (2005), when choosing e-learning as a university education method, basic requirements must be provided. The most important of these requirements are the skills of Faculty Members, such as computer skills and Internet services through training programs, ensuring appropriate technical and professional development, and raising personal and professional competence. (10: 165)

Such findings are consistent with the findings of Abdul Rahman Abdul Aziz (2015) 6, (Woods، R.Bakre, J\&Hopper, D.) (2004) (22), (Guven، Gulbahar (2008) (17), (Alothman، almosad) (2017) (15) In the existence of Impediments to the use of e-learning in teaching, which are related to Faculty Members, including that they do not have access to programs or courses related to the application of e-learning before engaging in teaching. Thus, it is difficult to move immediately from traditional 
learning to e-learning, together with the lack of material appreciation for their use of this type of learning.

\section{Third: Presentation and Discussion of Third Question's Results}

The Third Question states that:
3- What are the Impediments to the use of E-learning to teach Gymnastics course related to students and the order of its effect?

For answering such question, the frequency and arithmetic average of the responses of research sample related to students were calculated in order to determine the degree of Impediments effect and its Order from their point of view, and the results were as follows:

Table (5)

Ordering and Degree of Effect of Impediments Related to Students

\begin{tabular}{|c|c|c|c|c|c|}
\hline $\begin{array}{l}\text { Ordering By } \\
\text { Effect }\end{array}$ & $\begin{array}{l}\text { Number of Statement } \\
\text { on Questionnaire }\end{array}$ & Impediments & $\begin{array}{l}\text { Arithmetic } \\
\text { Average }\end{array}$ & $\begin{array}{c}\text { Standard } \\
\text { Deviation }\end{array}$ & $\begin{array}{l}\text { Degree of } \\
\text { Effect }\end{array}$ \\
\hline 1 & 30 & $\begin{array}{l}\text { Student preoccupation in websites of no relation to E- } \\
\text { learning }\end{array}$ & 4.4 & 0.67 & Very High \\
\hline 2 & 28 & $\begin{array}{l}\text { Student's lack of awareness for the importance of switching } \\
\text { from traditional learning to e-learning to study Gymnastics } \\
\text { course }\end{array}$ & 4.3 & 0.64 & Very High \\
\hline 4 & 32 & Lack of internet connection within some students' houses & 4.3 & 0.65 & Very High \\
\hline 5 & 35 & $\begin{array}{l}\text { Difficulty of using search engines to access educational } \\
\text { information through college internet network }\end{array}$ & 4.2 & 0.6 & Very High \\
\hline 6 & 29 & Lack of some students' skills in using computers & 4.1 & 0.54 & High \\
\hline 7 & 37 & $\begin{array}{l}\text { Faculty does not provide programs to train student on E- } \\
\text { learning skills }\end{array}$ & 3.8 & 0.6 & High \\
\hline 9 & 31 & $\begin{array}{l}\text { Lack of student access to support and direct guidance by } \\
\text { teachers when using e-learning }\end{array}$ & 3.5 & 0.67 & High \\
\hline 10 & 33 & $\begin{array}{c}\text { No awareness among students of the importance of e- } \\
\text { learning }\end{array}$ & 3.5 & 068 & High \\
\hline
\end{tabular}

Table (5) shows that the study sample agrees on all Impediments related to this axis. Impediments with the order of 1 to 5 were of "very high" effect, and study sample considers that student preoccupation in websites of no relation to E-learning is the most important Impediments related to this axis.

Impediments with order of 5 to 10 were of "high" effect; as study sample considers that the lack of some students' skills in using computers is one of the Impediments affecting the use of e-learning to teach Gymnastics course in such category.

Mandour (2009) points out that the lack of familiarity of learners with the skills of using modern technologies, such as computers and simulations, and their lack of training in e-learning techniques are of the Impediments of elearning. ( $13: 119$ )

These findings are consistent with those of the study of (Abdel Mohsen Abdel Razek) (2012), (8), (Anderson) (2008) (14) in the existence of Impediments to the use of e-learning in teaching, which are related to students, including lack of skills sufficient to use e-learning, lack of computer skills and the Internet as well as their preoccupation with sites of no relation to e-learning, lack of computers in some students at home, and the large number of students in lounges.

\section{Fourth, Presentation and Discussion of Fourth Question's Results}

The Fourth Question states that:

4-What are the Impediments to the use of E-learning to teach Gymnastics course related to Gymnastics course and the order of its effect?

For answering such question, the frequency and arithmetic average of the responses of research sample on Questionnaire statements related to Gymnastics course were calculated in order to determine the degree of Impediments effect and its Order from their point of view, and the results were as follows: 
Table (6)

Ordering and Degree of Effect of Impediments Related to Gymnastics Course

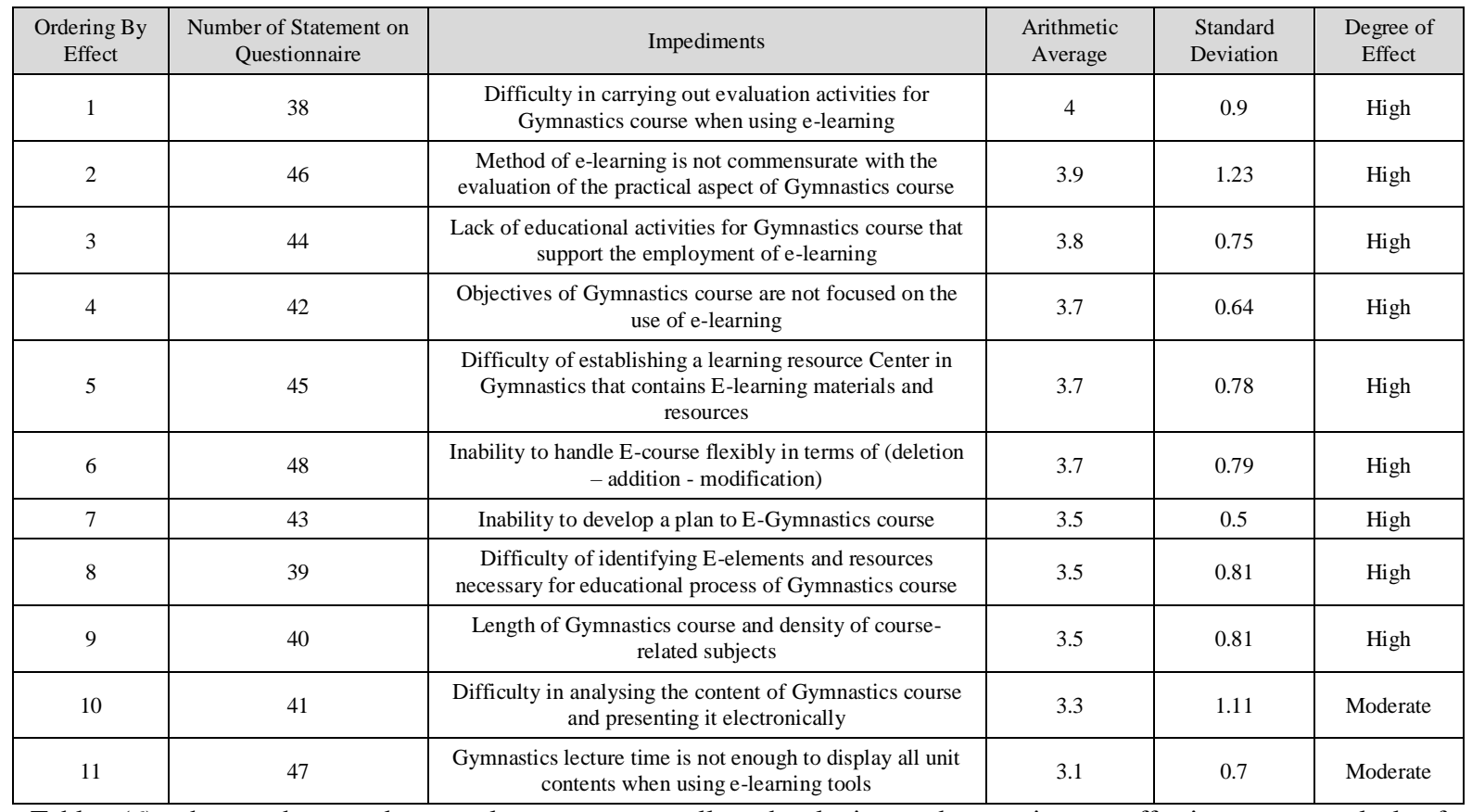

Table (6) shows that study sample agrees on all Impediments related to this axis. Impediments with the order of 1 to 9 were of "high" effect, and study sample considers that difficulty in carrying out evaluation activities for Gymnastics course when using e-learning is the most important Impediments related to this axis.

Impediments with order of 10 and 11 were of "moderate" effect; as study sample considers that difficulty in analysing the content of Gymnastics course and presenting it electronically are of moderate Impediments affecting the use of e-learning to teach Gymnastics.

Adeb Abdullah Al-Nawaysa (2007) points out that one of the Impediments to e-learning is the lack of standards for developing and operating an effective program, lack of ensuring that curricula is proceeding according to the plan developed for the same, difficulty of applying evaluation tools and methods, density of courses and incompatibility of courses with the rapid development of techniques. (2 : 223-224)

These findings are consistent with the study of (Sultan Abdul Aziz) (2017) (4), Conna (2007) (16), Anderson (2008) (14), sury. Daniel (2009) (21) In the existence of Impediments to the use of e-learning related to course, including difficulty of carrying out evaluation activities of courses, lack of adequacy of curriculum items for elearning tools, inability to handle curriculum flexibly and density of curriculum.

Table (7)

Ordering of E-learning Impediments According to Its Degree of Effect

\begin{tabular}{|c|c|c|c|c|}
\hline $\begin{array}{l}\text { Ordering By } \\
\text { Effect }\end{array}$ & $\begin{array}{c}\text { Impediments of Using E-Learning To Teach Gymnastics } \\
\text { Course }\end{array}$ & $\begin{array}{l}\text { Arithmetic Average of } \\
\text { Responses }\end{array}$ & $\begin{array}{c}\text { Standard } \\
\text { Deviation }\end{array}$ & $\begin{array}{l}\text { Degree of } \\
\text { Effect }\end{array}$ \\
\hline 1 & $\begin{array}{l}\text { Impediments related to Technical and Administrative } \\
\text { Aspects }\end{array}$ & 4.066 & 0.955 & High \\
\hline 2 & Impediments related to Students & 4.02 & 0.721 & High \\
\hline 3 & Impediments related to Gymnastics Course & 3.609 & 0.875 & High \\
\hline 4 & Impediments related to Faculty Members & 3.606 & 1.026 & High \\
\hline \multicolumn{2}{|r|}{ Total Average of Impediments } & 3.808 & 0.942 & High \\
\hline
\end{tabular}

Table (7) shows that Impediments of e-learning were achieved as a whole with a high degree of effect. The total average of Impediments reached (3.8 08). The first
Ordering in terms of degree of effect was the Impediments related to the technical and administrative aspects. In the second Order in terms of the degree of effect was 
Impediments related to students. In the third Order in terms of the degree of effect was Impediments related to Gymnastics. In the fourth Order in terms of the degree of effect was Impediments related to Faculty Members.

\section{Conclusions}

There are Impediments obstructing Faculty Members from using e-learning to teach Gymnastics courses in Faculties of Physical Education.

Impediments related to technical and administrative aspects were in the first order between study axes with an arithmetic average of (4.066). The most significant Impediments within the axis were the slow Internet connection and interruption of communication taking a lot of time in lecture.

2-Impediments related to students were in the second order among the axes of the study with an arithmetic average of (4.02). The most important Impediments within the axis is the preoccupation of students in sites of no relation to e-learning.

3-Impediments related to Gymnastics course were in the third order among the axes of the study with an arithmetic average of (3.609). The most important Impediments within the axis is the difficulty in carrying out evaluation activities for Gymnastics course when using e-learning.

4-Impediments related to Faculty Members were in the fourth order among the axes of the study with an arithmetic average of (3.606). The most important Impediments within the axis is the lack of internet points in the offices of Faculty Members.

\section{Recommendations}

1-Faculties of Physical Education should develop a strategy for e-learning and start developing infrastructure, and providing all material and human equipment.

2-Developing a plan to train all Faculty Members, students and technician supervising programs of implementing elearning.

3-Providing material and morale incentives to activate elearning in teaching.

4-Raising students' awareness to the importance of elearning.

5-Designing e-learning curricula, taking into consideration the needs and characteristics of learners.

6-Providing budgets to support the activation of e-learning at Faculties of Physical Education.

\section{References}

\section{Arabic References}

1. Ahmed Abdel-Fattah Hussein (2011): ": "The competencies of e-learning technology and their degree of availability among Faculty Members in the Faculty of Physical Education, Mansoura University in light of the faculty's strategy for teaching and learning, Scientific Journal of Physical Education and Sports Sciences، Issue.

17، Vol. I, Mansoura University.

2. Adeb Abd Allah al-Nawaisah (2007): Pedagogical Uses of EducationTechnology,First Edition, Dar Kanooz Al-Maa'refa, Amman.

3. El-Gharib Zaher Ismail: (2009): Electronic Courses "its Design- Production - Publishing - Application Evaluation", World of Books, Cairo."

4. Sultan Abdul Aziz Al- Bediwi (2017): Impediments to the use of e-learning from the point of view of Faculty Members at Al-Qassim University in the light of some variables., Journal of Faculty of Education, Issue 7, volume 33, Asyut University.

5. Abdel-Hamid Abdel-Aziz Talia (2010): Electronic Learning and Innovations of Education Technology, First Edition, Contemporary Library For Publishing and Distribution, Mansoura.

6. Abdurrahman Abdul-Aziz Al-Sarhan (2015): Difficulties Facing the Implementation of the Electronic Learning System at Shakra University from the Point of View of Specialized Experts, Journal of Qualitative Education, Issue 40, Mansoura University.

7. Abdullah Abdul Aziz Al-Mousa (2005): Using Computer in Education, Al-Ghad Library, Third Edition, Riyadh.

8. Abdul Mohsen Abdul Razek Al-Ghadian (2012): Electronic Learning, Challenges, Difficulties and Ways to Overcome, Journal of Faculty of Education, Volume 18, Issue 4, Helwan University.

9. Afaf Mohammed Tawfiq Zaho (2015): A Proposed Concept For Electronic Learning System in the Light of Comprehensive Quality Standards, Faculty of Education, Al-Baha University, Journal of Future of Arab Education, Issue 98, Volume 22, Journal of Future of Arab Education, Egypt.

10. Mohamed Ibrahim El-Desouki(2005): Building A Program in Education Technology To Develop Capacities of Faculty Members and Their Assistants in light of 
Training Needs and Activating Quality Departments, the 10th Conference of the Egyptian Society for E-learning Technology and Requirements of Comprehensive Quality, Cairo.

11. Mohammed Al-Kadah (2002): Computerization of Education- Teacher's Message, First Edition, Jordan.

12. Mohamed Fawzy Ahmed (2015): Impediments Facing Faculty Members at the Menoufia University When Using E-Learning Management Systems TMS, from their point of view, Journal of Faculty of Education, Volume 30, Issue 4, Menoufia University.

13. Mandour Abdel Salam Fathallah (2009): Interactive Learning Technology Tools, First Edition, Dar Alsomaie For Publishing, Riyadh.

\section{English References:}

14. Anderson,A.(2008):seven major challenges for Elearning in developing countries :case study EBIT, Srilanka . international journal of education and development using ICI , 4(3) available on : http://www.Ijedict.dec.uwi.edullviewarticle.phd?id=472\& lavout $=\mathrm{html}$.

15. Aothman,abdulrahman,Almosad,ahmedzead,(2017):m otivations and constraints of E-learning from the viewpoint offaculty members of the college of education ,king soud university, international journal for research in education : vol .41 :iss. 1 , article 4.

16. Conna,b.(2007)an investigation of incorporating online courses in public high school curricula retrieved ,10-Rodny,S.(2002)N. The integration of instructional technology into public education :Promises and challenges .Educational Technology, 1(42)

17. Gulbahar,y\&Guvan,I.(2008):A survey on ICT usage and perception of social studies teachers in turkey educational, technology \& society ,11(3),37-41.

18. Gyamfi.s\&Gyaase.p.(2015) students perception of blended learning environment : A case study of the university of education,winneba, Kumasi,Ghana.international , journal of education and development using information and communication technology (edict), vol.11,1ssuel,pp80-100

19. Means.b.\&Toyama.y.\&Murphy.r.\&Baki.m.(2013)the effectiveness of on line and blended learning : Ameta analysis of the empirical literature .teachers college record, volume 115, 030303,47pages.

20. Stevenson , Kimberleryn.(2007) : motivation and inhibiting factors affecting faculty participation in on line distance education,ph.D dissertation, East Carolina university, ( publication no .3285215AAT).

21. Sury .daniel w.(2009)implementation of web-based learning in colleges of education barriers and enablers, Canadian, journal of learning and technology,v.35,no.3.

22. Woods,R.Baker,J.\&Hopper.D.(2004):hybrid structures: Faculty Use and Perception of Web-Based Courseware as a Supplement to Face-to-Face Instruction, Internet and Higher Education, v7 n4 p281-297.

23. Young ,s,.(2004): In search of online pedagogical models: investigating a paradigm change in teaching through the School for All community, Journal for Computer Assisted Learning, Volume20, Issue2. 